\title{
Bovine embryo-oviduct interaction in vitro reveals an early cross talk mediated by BMP signaling
}

\author{
Elina V García ${ }^{1,2, *}$, Meriem Hamdi ${ }^{1} *$, Antonio D Barrera ${ }^{1,2}$, María J Sánchez-Calabuig ${ }^{1}$, \\ Alfonso Gutiérrez-Adán ${ }^{1}$ and Dimitrios Rizos ${ }^{1}$ \\ ${ }^{1}$ Departamento de Reproducción Animal, Instituto Nacional de Investigación y Tecnología Agraria y Alimentaria \\ (INIA), Madrid, Spain and ${ }^{2}$ Instituto Superior de Investigaciones Biológicas (INSIBIO), CONICET-UNT, and Instituto \\ de Biología 'Dr. Francisco D. Barbieri', Facultad de Bioquímica, Química y Farmacia, Universidad Nacional de \\ Tucumán, San Miguel de Tucumán, Tucumán, Argentina \\ Correspondence should be addressed to E V García; Email: evgarcia@fbqf.unt.edu.ar
}

*(E V García and M Hamdi contributed equally to this work)

\begin{abstract}
Signaling components of bone morphogenetic proteins (BMPs) are expressed in an anatomically and temporally regulated fashion in bovine oviduct. However, a local response of this signaling to the presence of the embryo has yet to be elucidated. The aim of the present study was to evaluate if early embryo-oviduct interaction induces changes in the gene expression of BMP signaling components. For this purpose, we used an in vitro co-culture system to investigate the local interaction between bovine oviductal epithelial cells (BOEC) from the isthmus region with early embryos during two developmental periods: before (from the 2-cell to 8-cell stage) or during (from the 8-cell to 16-cell stage) the main phase of embryonic genome activation (EGA). Exposure to embryos, irrespective of the period, significantly reduced the relative abundance of BMPR1B, BMPR2, SMAD1, SMAD6 and ID2 mRNAs in BOEC. In contrast, embryos that interacted with BOEC before EGA showed a significant increase in the relative abundance of $S M A D 1$ mRNA at the 8-cell stage compared to embryos cultured without BOEC. Moreover, embryos at the 16-cell stage that interacted with BOEC during EGA showed a significant increase in BMPR1B, BMPR2 and ID2 mRNA. These results demonstrate that embryo-oviduct interaction in vitro induces specific changes in the transcriptional levels of BMP signaling, causing a bidirectional response that reduces the expression levels of this signaling in the oviductal cells while increases them in the early embryo. This suggests that BMP signaling pathway could be involved in an early cross talk between the bovine embryo and the oviduct during the first stages of development.

Reproduction (2017) 153 631-643
\end{abstract}

\section{Introduction}

Maternal-embryo communication during the preimplantation period plays a critical role for the establishment and maintenance of pregnancy. Any disturbance in this reciprocal cross talk can lead to pregnancy failure and can also have long-term consequences in the developmental potential and health of the offspring (Wolf et al. 2003, Fazeli 2008, Rizos et al. 2016).

In mammals, the first maternal site that makes contact with the embryo is the oviduct. In the particular case of cattle, this contact is established during the first four days after fertilization (Maillo et al. 2016). Within this window of time, important developmental events occur in the embryo, including the first cleavage divisions (Lonergan et al. 1999) and the epigenetic reprogramming and activation of the embryonic genome (Memili \& First 2000, Graf et al. 2014). To provide an optimal environment and to ensure the correct synchronization of these events, the oviduct needs to initiate a molecular dialog with the developing embryo. Studies in mice, pigs and horses have provided evidence for this initial cross talk, demonstrating that the presence of the embryo(s) produces transcriptional changes in the oviductal cells (Lee et al. 2002, Almiñana et al. 2012, Smits et al. 2016). In cattle, although the presence of a single embryo in vivo has no detectable effect on the oviductal transcriptome, the transfer of 50 embryos into the oviduct of heifers produces changes in the gene expression pattern of the oviductal cells, suggesting that the effect of the embryo, particularly in mono-ovulatory species, seems to be more local than was expected (Maillo et al. 2015).

It is known that epithelial cells lining the lumen of the mammalian oviduct can synthesize and secrete a wide range of proteins, including diverse growth factors and cytokines that can mediate a local interaction with the 
embryo through different signaling pathways (Buhi et al. 2000, Lee \& Yeung 2006, Aviles et al. 2010). Among the candidate signaling pathways that could actively participate in this local embryo-maternal cross talk in the oviduct, we focused our attention on the signaling mediated by bone morphogenetic proteins (BMPs). BMPs are a subfamily of growth factors that belongs to the TGF- $\beta$ superfamily (Bragdon et al. 2011). These factors exert their effects as ligand dimers by binding to tetrameric complexes of type I (BMPR1A, BMPR1B or ACVR1A, also known as ALK3, ALK6 and ALK2 respectively) and type II (BMPR2, ACVR2A or ACVR2B) serine/threonine kinase receptors leading to signal transduction through SMAD-dependent pathways which regulates transcriptional responses (Beyer et al. 2013). Several BMPs are expressed in the maternal tract (ovary, uterus and placenta) and play important roles as autocrine and paracrine regulators of ovarian follicular development, blastocyst implantation in the uterus, and morphogenesis and organogenesis during embryo development (Shimasaki et al. 2004, Kishigami \& Mishina 2005, Jones et al. 2006, Knight \& Glister 2006). In addition, different components of the BMP signaling pathway are expressed by the embryo in a developmentally regulated fashion during the preimplantation development (Roelen et al. 1997, Zhang et al. 2007, Lee et al. 2014). Particularly in mice, knockout experiments and inhibition assays demonstrated that during the preimplantation period BMP signaling is critical for cell cleavage and the normal development of extra-embryonic lineages (Graham et al. 2014, de Mochel et al. 2015).

Previous studies have revealed that different members of the BMP family are expressed in the epithelial cells of the bovine oviduct in an anatomically and temporally regulated fashion during the estrous cycle (Garcia et al. 2014). In particular, BMP5 exhibits differential expression in the isthmus region and high transcriptional levels during the periovulatory phase. The presence of this factor in the oviductal fluid suggests that BMP ligands produced by the oviduct could have a paracrine action on the bovine embryo (Garcia et al. 2014). In fact, the addition of BMP5 to the culture medium during the first two days after fertilization produces an increase in the blastocyst rate and the relative mRNA abundance of pluripotency-related genes (Garcia et al. 2015). Interestingly, mRNA expression of BMP receptors is greater in early stage embryos (from 2 -cell to 8 -cell stage), suggesting that the embryo could be target of BMPs during its transit through the oviduct (Garcia et al. 2015). Moreover, in a recent study by RNA sequencing, Maillo and coworkers (Maillo et al. 2015) observed that the presence of multiple embryos induces changes in the expression levels of several genes in the bovine oviduct in vivo, included among them are various genes associated with the BMP signaling pathway. However, until now the participation of this signaling pathway in an initial cross talk between the embryo and the oviduct during the preimplantaion period has not been explored in depth.

Considering this evidence, BMP signaling could be a candidate pathway for embryo-maternal communication during the preimplantation period. Within this context, the objective of this study was to evaluate whether early embryo-oviduct interaction induces changes in the gene expression levels of BMP signaling components both in the oviductal cells and in the preimplantation embryos. For this purpose, an in vitro co-culture system allowing a local and temporal interaction between early bovine embryos and isthmus epithelial cells was established.

\section{Materials and methods}

\section{Chemicals}

All reagents were purchased from Sigma Chemical Química S.A Company unless otherwise stated.

\section{Bovine oviduct epithelial cell isolation and in vitro culture}

Bovine oviducts at the early luteal phase (corresponding to Days 3-5 of the estrous cycle) were obtained from slaughtered heifers and selected based on ovarian morphology according to Ireland and coworkers (Ireland et al. 1980). The oviducts were sealed in a plastic bag and transported to the laboratory on ice within $2 \mathrm{~h}$ of slaughter. The surrounding fat and connective tissues were carefully removed and each oviduct was washed three times in sterile PBS $(\mathrm{pH}$ 7.4). The isthmus region was separated and the oviductal mucosa was collected by squeezing and was washed 2 times with PBS by centrifugation at $300 \mathrm{~g}$ for $10 \mathrm{~min}$. The cell pellet was then resuspended in $1 \mathrm{~mL}$ of synthetic oviductal fluid (SOF) supplemented with $10 \%(\mathrm{v} / \mathrm{v})$ of fetal calf serum (FCS) and was passed 10 times through a $25 \mathrm{G}$ syringe needle to obtain a single cell suspension. Bovine oviduct epithelial cells (BOEC) were counted in a hemocytometer, diluted to a final concentration of $2 \times 10^{6} \mathrm{cells} / \mathrm{mL}$ and then cultured in $500 \mu \mathrm{L}$ of SOF $+10 \%$ FCS in four-well plates at $38.5^{\circ} \mathrm{C}, 5 \% \mathrm{CO}_{2}, 5 \%$ $\mathrm{O}_{2}, 90 \% \mathrm{~N}_{2}$ and saturated humidity until confluence. Half of the media (SOF $+10 \%$ FCS) was replaced every $48 \mathrm{~h}$. On Day 5 of culture, the medium was changed to SOF with $5 \%$ FCS; and $24 \mathrm{~h}$ later, half of the media was renewed and the cells were used for co-culture with embryos.

Immunocytochemical analysis with antibodies anti-bovinepancadherin (C1821), anti-bovine-pancytokeratin (C2931) and anti-bovine-vimentin (V2258), following the protocol described by Lopera-Vásquez and coworkers (LoperaVásquez et al. 2016), confirmed the epithelial nature of the cultured cells showing positive staining for the epithelial markers cadherin and cytokeratin, and negative staining for the fibroblast marker vimentin (Fig. 1A). 


\section{A Cadherin}

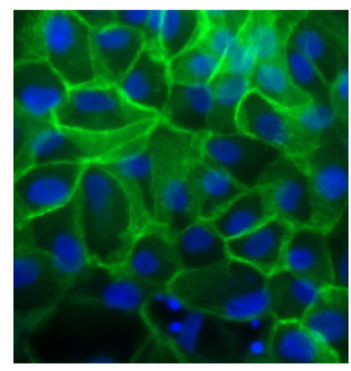

B

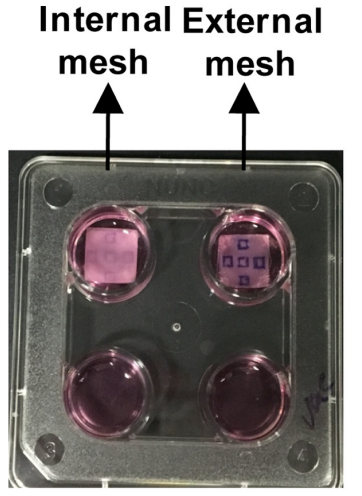

Cytokeratin

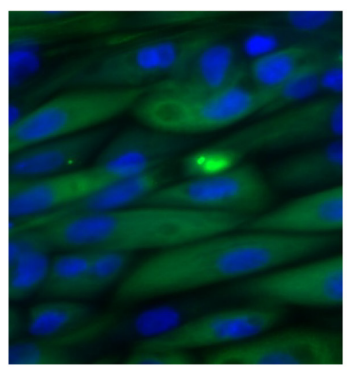

\section{Polyester mesh over BOEC monolayer}

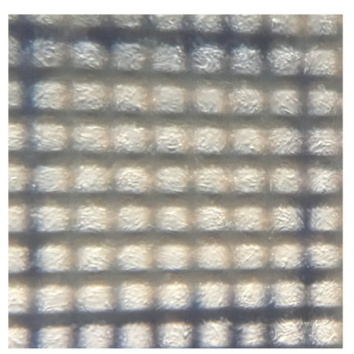

Vimentin

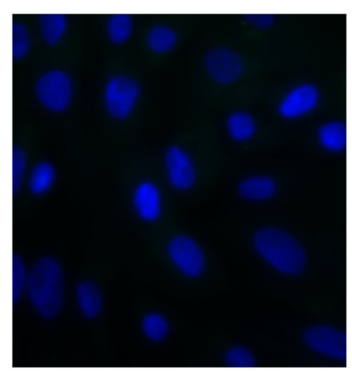

Embryos in the area of co-culture

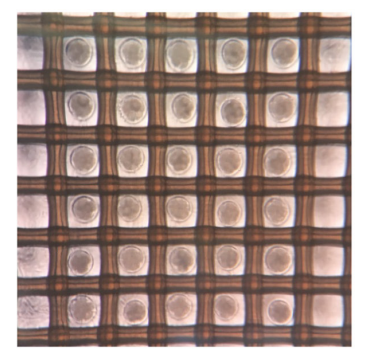

Figure 1 In vitro co-culture system. (A) Immunofluorescence analysis of BOEC monolayers showing positive staining for the epithelial markers, cadherin and cytokeratin, and negative staining for the fibroblast marker, vimentin. Cell nuclei were counterstained with Hoechst stain (blue). (B) Representative image of the polyester meshes employed to establish a local area of contact between the embryos and the BOEC monolayer. Thirty embryos/well were transferred to the mesh and placed in a $6 \times 5$ openings grid covering an area of $2.1 \mathrm{~mm}^{2}$ over the monolayer. Mesh dimensions: $170 \mu \mathrm{m}$ opening and $96 \mu \mathrm{m}$ filament diameter.

\section{Oocyte collection and in vitro maturation}

Immature cumulus-oocyte complexes (COCs) were recovered by aspirating follicles $(2-8 \mathrm{~mm}$ in diameter) from ovaries of heifers slaughtered at local abattoir and in vitro maturation was performed as described by Lopera-Vásquez and coworkers (Lopera-Vásquez et al. 2015). Only oocytes with a compact, non-atretic cumulus of at least three layers and a homogeneous ooplasm (Class 1 and 2 COCs) were selected and matured for $24 \mathrm{~h}$ in $500 \mu \mathrm{L}$ of maturation medium (TCM 199 (M4530) supplemented with 10\% (v/v) FCS and $10 \mathrm{ng} / \mathrm{mL}$ epidermal growth factor (E4127)) in four-well dishes (50 COCs per well) at $38.5^{\circ} \mathrm{C}$ under an atmosphere of $5 \% \mathrm{CO}_{2}$, with maximum humidity.

\section{In vitro fertilization}

Frozen semen from a single Asturian Valley bull (ASEAVA, Asturias, Spain), previously tested for IVF, was thawed at $37^{\circ} \mathrm{C}$ in a water bath for $1 \mathrm{~min}$ and selected on a gradient of Bovipure (Nidacon Laboratories AB, Göthenborg, Sweden) following the protocol described by Lopera-Vázquez and coworkers (Lopera-Vázquez et al. 2016). Sperm concentration was determined and adjusted to a final concentration of $1 \times 10^{6}$ sperm cells $/ \mathrm{mL}$. Gametes were coincubated for $18-22 \mathrm{~h}$ in $500 \mu \mathrm{L}$ of fertilization medium (Tyrode's medium with $25 \mathrm{mM}$ bicarbonate, $22 \mathrm{mM} \mathrm{Na}$-lactate, $1 \mathrm{mM} \mathrm{Na-pyruvate}$ and $6 \mathrm{mg} / \mathrm{mL}$ fatty acid-free bovine serum albumin (BSA) supplemented with $10 \mu \mathrm{g} / \mathrm{mL}$ heparin sodium salt (Calbiochem)) in a four-well dish, in groups of 50 COCs per well under an atmosphere of $5 \% \mathrm{CO}_{2}$, with maximum humidity at $38.5^{\circ} \mathrm{C}$.

\section{In vitro embryo culture and co-culture conditions}

After the fertilization period, presumptive zygotes were completely denuded of cumulus cells by vortexing and groups of 50 were initially cultured in $500 \mu \mathrm{L}$ of SOF supplemented with $4.2 \mathrm{mM}$ sodium lactate (L4263), $0.73 \mathrm{mM}$ sodium pyruvate (P4562), 30 $\mu \mathrm{L} / \mathrm{mL}$ basal medium eagle (BME) amino acids (B6766), $10 \mu \mathrm{L} / \mathrm{mL}$ minimum essential medium (MEM) amino acids (M7145), $1 \mu \mathrm{g} / \mathrm{mL}$ phenol red (P0290) and $3 \mathrm{mg} / \mathrm{mL}$ bovine serum albumin (BSA; A9647) in a four-well dish, under an atmosphere of $5 \% \mathrm{CO}_{2}, 5 \% \mathrm{O}_{2}$ and $90 \% \mathrm{~N}_{2}$ at $38.5^{\circ} \mathrm{C}$. At 33 and $54 \mathrm{~h}$ post-insemination (hpi); those embryos that reach the 2-cell stage and the 8-cell stage respectively were selected and randomly cultured in groups of 30 embryos in SOF supplemented with $3 \mathrm{mg} / \mathrm{mL}$ of BSA or in SOF supplemented with $5 \%(\mathrm{v} / \mathrm{v})$ of FCS in the presence or absence of a BOEC monolayer, depending on the experimental group to which they were assigned (see 'Experimental design' described below for more details). In order to limit and establish a local area of contact between the embryos and the BOEC monolayer, a nontoxic woven polyester mesh (Sefar Petex; Sefar, Bury, Lancashire, UK) was used with a grid size of $41 \times 41$ openings, covering an area of $121 \mathrm{~mm}^{2}$ that fitted perfectly inside the well of a NuncTM 4-well dish. First of all, one mesh square containing delimited marked areas of $6 \times 5$ openings was placed outside at the bottom of the wells and was used as a guide to localize the co-culture area (Fig. 1B). Secondly, another mesh square of the same size was washed once with $70 \%$ ethanol, thrice with PBS and twice with SOF media, and then was introduced into the well so that the external and internal mesh were overlapped. Then, 30 embryos/well were 
transferred to the mesh and placed in a $6 \times 5$ grid, covering an area of $2.1 \mathrm{~mm}^{2}$ over the monolayer (Fig. 1B). Preferably, the central grid was selected. Following culture, embryos were transferred and cultured in $25 \mu \mathrm{L}$ droplets of SOF with BSA until Day 9 pi.

\section{$R N A$ isolation and reverse transcription}

Five independent samples of BOEC cultured with and without embryo under each experimental condition, and also three independent groups of 10 embryos per stage (8-cell, 16-cell and blastocyst stage) and per experimental group were collected and processed for poly(A) RNA extraction. Poly(A) RNA was extracted using the Dynabeads mRNA Direct Extraction Kit (Dynal Biotech, Oslo, Norway) following the manufacturer's instructions and with minor modifications as it was described previously by Bermejo-Alvarez and coworkers (Bermejo-Alvarez et al. 2008). After 10 min of incubation in lysis buffer with Dynabeads, poly(A) RNA attached to the Dynabeads was extracted with a magnet and washed twice in washing buffer A and washing buffer B. RNA was then eluted with Tris- $\mathrm{HCl}$. Immediately after extraction, the reverse transcription (RT) reaction was performed as recommended by the manufacturer (Epicentre Technologies Corp, Madison, WI, USA). Briefly, oligo-dT $(0.2 \mu \mathrm{M})$ and random primers $(0.5 \mu \mathrm{M})$ were added to each RNA sample and were heated for $5 \mathrm{~min}$ at $70^{\circ} \mathrm{C}$ to denature the secondary RNA structure. Next, the tubes were incubated at $25^{\circ} \mathrm{C}$ for $10 \mathrm{~min}$ to promote the annealing of the primers. Then, the RNA was reverse-transcribed for $60 \mathrm{~min}$ at $37^{\circ} \mathrm{C}$ in a final volume of $50 \mu \mathrm{L}$ containing $0.375 \mathrm{mM} d \mathrm{NTPs}$ (Biotools, Madrid, Spain), 6.25U RNasin RNAse inhibitor (Promega), 10× MMLV-RT buffer with $8 \mathrm{mM}$ dithiothreitol and $5 \cup$ MMLV high performance reverse transcriptase (Epicentre Technologies Corp, Madison, WI, USA), followed by incubation at $85^{\circ} \mathrm{C}$ for 5 min to inactivate the RT enzyme.

\section{Gene expression analysis}

The mRNA expression levels of the selected genes were determined by real-time quantitative reverse transcription polymerase chain reaction (qRT-PCR) using specific primers designed with Primer-BLAST (http://www.ncbi.nlm.nih.gov/ tools/primer-blast/) to span exon-exon boundaries when possible. Primers (Table 1) were previously validated for adequate primer efficiency; and specificity of their PCR products was confirmed by electrophoresis on a $2 \%$ agarose gel. All target genes showed efficiencies between 97 and $100 \%$ and correlation coefficients close to 1.0.

All PCR reactions were performed in a final volume of $20 \mu \mathrm{L}$, containing $0.25 \mathrm{mM}$ of forward and reverse primers, $10 \mu \mathrm{L}$ of GoTaq qPCR Master Mix (Promega) and $2 \mu \mathrm{L}$ of each cDNA sample derived from BOEC $(\approx 60 \mathrm{ng} / \mu \mathrm{L})$, 8-cell embryos $(\approx 4 \mathrm{ng} / \mu \mathrm{L})$, 16 -cell embryos $(\approx 20 \mathrm{ng} / \mu \mathrm{L})$ or blastocysts $(\approx 60 \mathrm{ng} / \mu \mathrm{L})$, using a Rotorgene 6000 Real Time Cycler (Corbett Research, Sydney, Australia) and SYBR Green as doublestranded DNA-specific fluorescent dye. For each experimental group, five different cDNA samples from BOEC and three different cDNA samples from each embryonic stage were used in two repetitions for all genes of interest. The PCR program consisted of an initial denaturalization step at $94^{\circ} \mathrm{C}$ for $2 \mathrm{~min}$, followed by 35 cycles of denaturalization at $94^{\circ} \mathrm{C}$ for $10 \mathrm{~s}$, annealing at $56^{\circ} \mathrm{C}$ for $30 \mathrm{~s}$, extension at $72^{\circ} \mathrm{C}$ for $15 \mathrm{~s}$ and $10 \mathrm{~s}$ of fluorescence acquisition defined for each primer. At the end of each PCR run, melt curve analyses were performed for all

Table 1 Set of primers used for qRT-PCR assays.

\begin{tabular}{|c|c|c|c|c|}
\hline \multirow{2}{*}{$\frac{\text { Gene }}{B M P 5}$} & \multicolumn{2}{|c|}{ Primer sequences $\left(5^{\prime}-3^{\prime}\right)^{\mathbf{a}}$} & \multirow{2}{*}{$\begin{array}{c}\text { Amplicon length }(\mathrm{bp}) \\
271\end{array}$} & \multirow{2}{*}{$\begin{array}{l}\text { GenBank accession number } \\
\text { NM_001305016.1 }\end{array}$} \\
\hline & Forward & GATGTGGGTTGGCTTGTCTT & & \\
\hline & Reverse & CCTGATGAGAGCCGGATTTA & & \\
\hline \multirow[t]{2}{*}{$B M P 7$} & Forward & AACCATGCCATCGTGCAGACGC & 250 & NM_001206015.1 \\
\hline & Reverse & AAGCCCGGACAACCATGTTTGC & & \\
\hline \multirow[t]{2}{*}{ BMPR1A } & Forward & TTGGGAAATGGCTCGTCGTT & 142 & NM_001076800.1 \\
\hline & Reverse & AGACACAATTGGCCGCAAAC & & \\
\hline \multirow[t]{2}{*}{$B M P R 1 B$} & Forward & TTTGGGAGGTCGCTAGGAGA & 132 & NM_001105328.1 \\
\hline & Reverse & GCCGCAGCTTCTTGATACAC & & \\
\hline \multirow[t]{2}{*}{ BMPR2 } & Forward & TCTTTCAGCСАССАATGTССТ & 158 & NM_001304285.1 \\
\hline & Reverse & GTTCAGTGGAAATGACCCAGG & & \\
\hline \multirow[t]{2}{*}{ SMAD1 } & Forward & TGTGAACCACGGCTTCGAGACG & 99 & NM_001076223.2 \\
\hline & Reverse & TCCTGGCGGTGGTATTCTGCTC & & \\
\hline \multirow[t]{2}{*}{ SMAD5 } & Forward & TTGCTCAGCTTCTGGCTCAGTC & 119 & NM_001077107.3 \\
\hline & Reverse & TTGCCGGTGATACTCTGСТCC & & \\
\hline \multirow[t]{2}{*}{ SMAD6 } & Forward & GGAGAAATTCGCTCCAAGTGC & 242 & NM_001206145.1 \\
\hline & Reverse & СССТGССТTTAАAАСССАAGC & & \\
\hline \multirow[t]{2}{*}{ ID2 } & Forward & CGACATCAGCATCCTGTCCTT & 145 & NM_001034231.2 \\
\hline & Reverse & AGAGCCTGTGGATTTGTTGT & & \\
\hline \multirow[t]{2}{*}{$H 2 A F Z$} & Forward & AGGACGACTAGCCATGGACGTGTG & 209 & NM_174809.2 \\
\hline & Reverse & CCACCACCAGCAATTGTAGCCTTG & & \\
\hline \multirow[t]{2}{*}{ ACTB } & Forward & GAGAAGCTCTGCTACGTCG & 263 & NM_173979.3 \\
\hline & Reverse & CCAGACAGCACCGTGTTGG & & \\
\hline
\end{tabular}

${ }^{a}$ All the primers were designed with NCBI Primer-BLAST online tool of the National Centre for Biotechnology Information (http://www.ncbi.nlm. nih.gov/tools/primer-blast/). 
genes to ensure single product amplification and exclude the possible interference of dimers.

Relative expression levels were quantified by the comparative cycle threshold $(\Delta \Delta \mathrm{CT})$ method (Schmittgen \& Livak 2008). Values were normalized using two housekeeping genes ( $H 2 A F Z$ and ACTB) that were tested in previous studies (Maillo et al. 2015). Fluorescence was acquired in each cycle to determine the threshold cycle during the log-linear phase of the reaction at which fluorescence increased above background for each sample. According to the comparative CT method, the $\triangle \mathrm{CT}$ value was determined by subtracting the mean CT value of the two housekeeping genes ( $H 2 A F Z$ and $A C T B$ ) for each sample from each gene CT value of the sample. Calculation of $\Delta \Delta C T$ involved using the highest sample $\Delta C T$ value (i.e. the sample with the lowest target expression) as an arbitrary constant to subtract from all other $\Delta \mathrm{CT}$ sample values. Fold changes in the relative gene expression of the target were determined using the formula $2^{-\Delta \Delta C T}$ (Livak \& Schmittgen 2001). All the study were carried out following the Minimum Information for Publication of Quantitative Real-Time PCR Experiments recommendations (Bustin et al. 2009).

\section{Experimental design}

\section{Experiment 1: Effect of BOEC co-culture on early embryo development in vitro}

In the first experiment, an in vitro co-culture system was established to provide a local and temporal interaction between a BOEC monolayer and early bovine embryos during two developmental periods: (a) Experimental Group 1 (G1): from 2-cell to 8-cell stage, before the main phase of embryonic genome activation (EGA); and (b) Experimental Group 2 (G2): from 8-cell to 16-cell stage, during the main phase of EGA (Fig. 2). To determine if this in vitro co-culture system had an effect on early embryonic development, cleavage rate and blastocyst yield were evaluated.

For this purpose, isthmus epithelial cells obtained from a pool of three post-ovulatory stage oviducts $(n=21,3$ oviducts per experimental replicate) were cultured in a monolayer as described previously. On Day 6 of culture, the BOEC monolayer was cultured in the absence or presence of in vitro-produced embryos from 2- to 8-cell stage (G1 BOEC; 33-54 hpi) or from 8- to 16-cell stage (G2 BOEC; 54-98hpi) in SOF medium supplemented with $5 \%$ FCS, under an atmosphere of $5 \%$ $\mathrm{CO}_{2}, 5 \% \mathrm{O}_{2}$ and $90 \% \mathrm{~N}_{2}$ at $38.5^{\circ} \mathrm{C}$. As mentioned above, 30 embryos/well were placed in a $6 \times 5$ grid over the monolayer. In addition, as control without BOEC, groups of 30 embryos in both developmental stages were cultured either in SOF $+5 \%$ FCS (G1 FCS and G2 FCS) or in SOF $+3 \mathrm{mg} / \mathrm{mL}$ BSA (G1 $\mathrm{BSA}$ and G2 BSA). At $54 \mathrm{hpi}$ (G1 BOEC/FCS/BSA) or $98 \mathrm{hpi}$ (G2 BOEC/FCS/BSA), embryos that reached the 8- or 16-cell stage respectively were transferred to SOF $+\mathrm{BSA}$ and cultured until Day 9, maintaining the different experimental groups separately (Fig. 2).

Considering that during the experiment it was necessary to preselect the embryos at different stages of development, the developmental parameters were calculated as follows: (I) developmental rate at $33 \mathrm{hpi}$ : percentage of presumptive zygotes that developed to the 2-cell stage at $33 \mathrm{hpi}$; (II) developmental rate at $54 \mathrm{hpi}$ : percentage of selected 2-cell embryos that developed to the 8 -cell stage at $54 \mathrm{hpi}$; (III) developmental rate at $98 \mathrm{hpi}$ : percentage of selected 8-cell embryos that developed to the 16-cell stage at $98 \mathrm{hpi}$; and

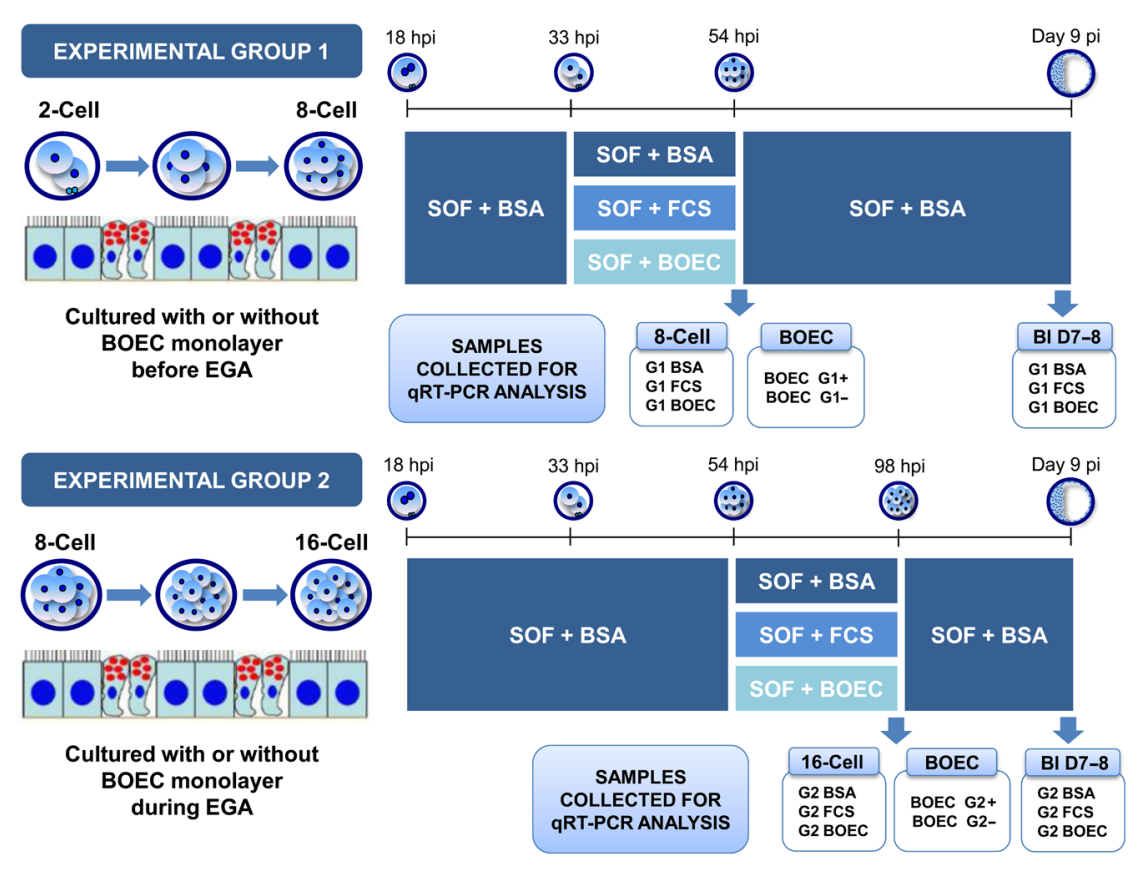

Figure 2 Experimental design. Experimental group 1: Two-cell IVF bovine embryos were selected at $33 \mathrm{hpi}$ and cultured before the main phase of EGA (from 2-cell to 8-cell stage: $33-54 \mathrm{hpi}$ ) in medium SOF + BSA (G1 BSA), SOF+FCS (G1 FCS) or co-cultured with BOEC monolayer (G1 BOEC). At 54 hpi, embryos that reached the 8-cell stage were transferred to SOF + BSA and cultured until Day 9. Experimental group 2: Eight-cell IVF bovine embryos were selected at $54 \mathrm{hpi}$ and cultured during the main phase of EGA (from 8-cell to 16-cell stage: $54-98 \mathrm{hpi}$ ) in medium SOF + BSA (G2 BSA), SOF + FCS (G2 FCS) or co-cultured with BOEC monolayer (G2 BOEC). At $98 \mathrm{hpi}$, embryos that reached the 16-cell stage were transferred to SOF + BSA and cultured until Day 9. Samples of BOEC cultured with (BOEC $\mathrm{G} 1+/ \mathrm{G} 2+$ ) or without embryos (BOEC G1-/G2-) before or during EGA, and embryos at 8-cell (54hpi), 16-cell (98 hpi) and blastocyst stage (Day 7-8) were collected from the different experimental groups to evaluate the mRNA expression levels of BMP signaling components by qRT-PCR. EGA, embryonic genome activation; hpi, hours post insemination. 
(IV) blastocyst yield: percentage of selected 8-cell embryos or 16-cell embryos that continued in culture and developed to the blastocyst stage at Days 7, 8 and 9 after insemination.

Seven experimental replicates were performed under the same assay conditions and a total of 2550 presumptive zygotes were in vitro cultured: 1192 were used for experimental groups 1 (G1 BOEC/FCS/BSA) and 1358 for groups 2 (G2 BOEC/FCS/BSA).

\section{Experiment 2: Effect of early embryo-oviduct interaction in vitro on $m R N A$ expression of BMP signaling components in oviductal epithelial cells}

To evaluate whether in vitro interaction with early embryos induces changes in the gene expression levels of BMP signaling components in the oviductal cells, an expression analysis was performed by qRT-PCR in 5 samples of BOEC cultured with or without embryos before (G1 BOEC) or during EGA (G2 BOEC), obtained from 5 different experimental replicates of Experiment 1.

After the co-culture period, the polyester mesh and the embryos were removed and the BOEC monolayer was quickly washed twice with PBS. The cell area directly beneath the embryos was recovered from G1 BOEC at $54 \mathrm{hpi}(\mathrm{BOEC} \mathrm{G1+,n=5)}$ and from G2 BOEC at $98 \mathrm{hpi}(\mathrm{BOEC} \mathrm{G} 2+, n=5$ ) by mechanical scraping with a micropipette tip. At the same time, an area of the same size but from a different well of BOEC, cultured without embryos, was collected as control (BOEC G1- and BOEC G2-; $n=5$ ). The BOEC samples collected were immediately snap-frozen in liquid nitrogen and kept at $-80^{\circ} \mathrm{C}$ until RNA extraction.

The mRNA expression levels of two BMP ligands (BMP5/7), three $\mathrm{BMP}$ receptors $(B M P R 1 A / 1 B / 2)$, two signaling proteins $(S M A D 1 / 5)$, one inhibitor (SMAD6) and one target gene (ID2) were analyzed by qRT-PCR according to the procedures described above.

\section{Experiment 3: Effect of early embryo-oviduct interaction in vitro on $m R N A$ expression of BMP signaling components in preimplantation embryos}

The objective of the third experiment was to evaluate if the in vitro interaction with the oviductal cells induces changes in the expression levels of BMP signaling components in the embryos at specific developmental stages. For this purpose, gene expression analysis by qRT-PCR was performed in three independent groups of 10 embryos per stage (8-cell, 16-cell and blastocyst stage) obtained from each experimental group that was cultured with or without BOEC, before or during EGA (corresponding to groups 1 (G1 BOEC/BSA/FCS) and groups 2 (G2 BOEC/BSA/FCS) respectively) in Experiment 1.

After the co-culture period, at $54 \mathrm{hpi}$ (G1 BOEC/FCS/BSA) or 98 hpi (G2 BOEC/FCS/BSA), embryos that reached the 8- or 16 -cell stage respectively were removed, quickly washed in PBS; and 10 embryos per stage and experimental group were immediately snap-frozen in liquid nitrogen and kept at $-80^{\circ} \mathrm{C}$ until RNA extraction. The remaining embryos were transferred to $25 \mu \mathrm{L}$ droplets of SOF + BSA under mineral oil and cultured until Day 9 pi. At Day 7-8 pi, pools of 10 expanding blastocysts per treatment were collected, snap-frozen and stored at $-80^{\circ} \mathrm{C}$ until use for gene expression analysis.
The mRNA expression levels of two BMP ligands (BMP5/7), three $B M P$ receptors $(B M P R 1 A / 1 B / 2)$, two signaling proteins $(S M A D 1 / 5)$, one inhibitor (SMAD6) and one target gene (ID2) were analyzed by qRT-PCR according to the procedures described above.

\section{Statistical analysis}

Data were analyzed using SigmaStat 3.5 and SigmaPlot 10.0 statistical software (Systat Software, Richmond, CA, USA). Cleavage rate, blastocyst yield and relative mRNA abundance levels were analyzed using one-way analysis of variance (ANOVA), followed by Holm-Sidak post hoc test, when applicable, to determine statistical differences between the experimental groups. Probability values less than 0.05 $(P \leq 0.05)$ were considered statistically significant.

\section{Results \\ Experiment 1: Effect of BOEC co-culture on early embryo development in vitro}

For all the experimental groups, only embryos that reached the 2 -cell stage at $33 \mathrm{hpi}$ were selected for the study. As shown in Fig. 3A cleavage rates at $33 \mathrm{hpi}$ were similar for G1 and G2 (G1: $66.8 \pm 2.0 \%$ vs G2: $67.6 \pm 1.2 \% ; P>0.05)$. In general, most of the embryos reached the 2 -cell stage at $33 \mathrm{hpi}(\mathrm{G} 1: 53.9 \pm 3.8 \%$ and G2: $58.8 \pm 3.5 \%$ ) and a low percentage of embryos were at a more advanced stage (G1: $12.8 \pm 3.5 \%$ and G2: $8.8 \pm 2.7 \%$ )

At $54 \mathrm{hpi}$ in the G1 BOEC group, a lower proportion of embryos reached the 8-cell stage than control groups (G1 BOEC: $57.1 \pm 4.9 \%$ vs G1 BSA: $78.6 \pm 4.0 \%$ and G1 FCS: $79.0 \pm 7.4 \% P<0.05$ ) (Fig. 3B). As a consequence, a significantly higher proportion of embryos with a delayed development ( $<8$ cells) was observed in G1 BOEC than control groups (G1 BOEC: $42.9 \pm 4.9 \%$ vs G1 BSA: $21.4 \pm 4.0 \%$ and G1 FCS: $21.0 \pm 7.4 \%$, $P<0.05)$ (Fig. 3B).

Similarly, at $98 \mathrm{hpi}$, the G2 BOEC group showed a lower but not significant proportion of embryos reaching the 16-cell stage than control groups (G2 BOEC: $52.4 \pm 8.4 \%$, G2 BSA: $66.7 \pm 5.9 \%$ and G2 FCS: $65.2 \pm 6.8 \%$ ) (Fig. 3C). In this case, a significantly higher proportion of embryos with a delayed development ( $<16$ cells) was observed in the G2 BOEC group in comparison with the control groups (G2 BOEC: $47.6 \pm 8.4 \%$ vs G2 BSA: $33.3 \pm 5.9 \%$ and G2 FCS: $34.8 \pm 6.8 \%, P<0.05$ ) (Fig. 3C).

Despite this initial delay observed in the developmental kinetics of the embryos, no significant differences were observed in the blastocyst rate between the control groups (G1 BSA/FCS and G2 $\mathrm{BSA} / \mathrm{FCS}$ ) and the groups that were CO-cultured with BOEC before or during EGA (G1 BOEC or G2 BOEC) (Fig. 3D and E). 

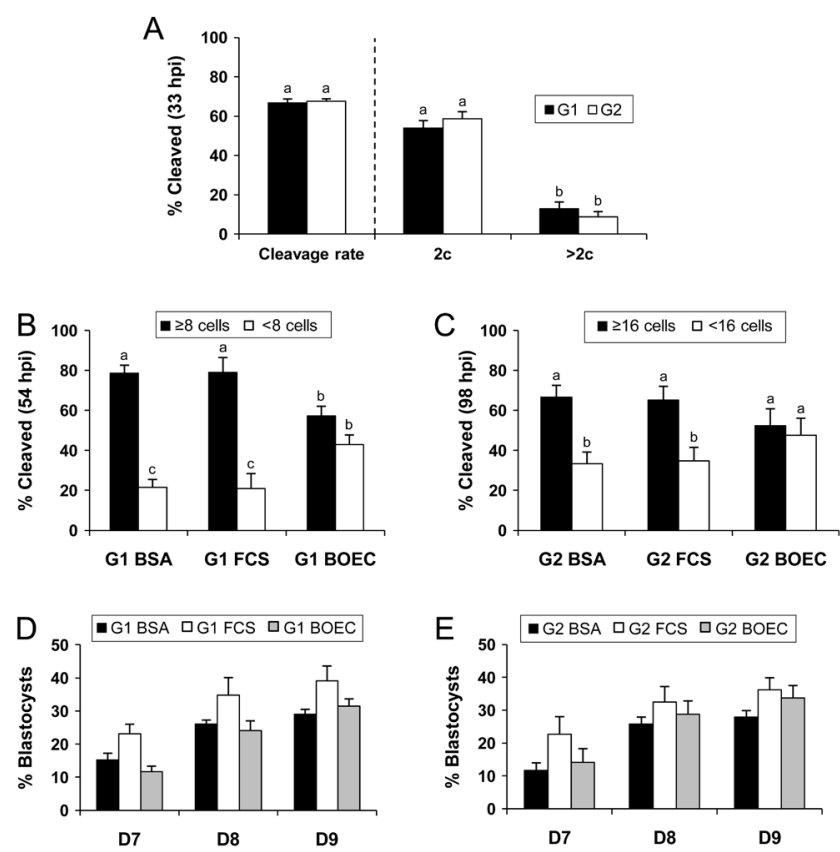

Figure 3 Developmental rates of in vitro-produced bovine embryos cultured before or during embryonic genome activation with or without BOEC. (A) Cleavage rate at $33 \mathrm{~h}$ post-insemination (hpi) and percentages of IVF embryos that reached the 2-cell stage (2c) or more (>2c), from G1 and G2 experimental groups. (B) Developmental rate at $54 \mathrm{hpi}$ for experimental groups 1 (G1 BSA/FCS/BOEC).

(C) Developmental rate at $98 \mathrm{hpi}$ for experimental groups 2 (G2 BSA/ FCS/BOEC). (D) Blastocyst rate at Days 7-9 pi (in vitro

fertilization = Day 0) derived from experimental groups 1 (G1 BSA/ FCS/BOEC). (E) Blastocyst rate at Days 7-9 pi derived from experimental groups 2 (G2 BSA/FCS/BOEC). Results are expressed as mean \pm S.E.M. Significant differences $(P<0.05)$ are indicated with different letters. G1: embryos cultured from 2-cell stage to 8-cell stage in medium SOF+BSA (G1 BSA), SOF + FCS (G1 FCS) or co-cultured with a BOEC monolayer (G1 BOEC). G2: embryos cultured from 8-cell stage to 16-cell stage in medium SOF + BSA (G2 BSA), SOF + FCS (G2 FCS) or co-cultured with a BOEC monolayer (G2 BOEC).

\section{Experiment 2: Effect of early embryo-oviduct interaction in vitro on $m R N A$ expression of $B M P$ signaling components in oviductal epithelial cells}

Gene expression analysis in BOEC showed that the interaction with the embryos, before and during the main phase of EGA, produced a decrease in the mRNA expression levels of $B M P 7, B M P R 1 B, B M P R 2$, SMAD1, SMAD6 and ID2 compared with the significant higher levels detected in those transcripts when BOEC were cultured without embryos (Fig. 4). The embryonic presence produced a similar transcriptional response in the oviductal cells, irrespective of the embryonic stage.

On the other hand, expression levels of BMPR1A and SMAD5 mRNA tended to be similar to those levels observed for BMP7 mRNA. However, the relative abundance of BMPR1A and SMAD5 transcripts did not show significant differences between BOEC cultured with or without embryos (Fig. 4). In the particular case of $B M P 5$, the expression of its mRNA was not detected in the oviductal cells cultured in vitro. In this case, to confirm that BMP5 primers work efficiently, samples of bovine oviduct epithelial cells freshly obtained from the isthmus region (BOEC in vivo) were used as positive control (data not shown).

\section{Experiment 3: Effect of early embryo-oviduct interaction in vitro on $m R N A$ expression of BMP signaling components in preimplantation embryos}

Gene expression analysis in early stage embryos revealed a different transcriptional response to the interaction with BOEC, depending on the embryonic stage in which they interacted. At the 8-cell stage, embryos from G1 BOEC group showed a significant increase in the relative abundance of SMAD1 mRNA, compared to the levels detected in embryos derived from control groups (G1 BSA and G1 FCS) (Fig. 5A). Moreover, at the 16-cell stage, embryos from G2 BOEC group showed a significant increase in the relative abundance of BMPR1B, BMPR2 and ID2 mRNA compared to controls (G2 BSA and G2 FCS) (Fig. 5B). Despite these transcriptional changes detected in early stage embryos, in general, no differences were observed in the mRNA expression levels of BMP signaling components between the blastocysts obtained from the different experimental groups cultured in the presence or absence of BOEC (Fig. 6).

\section{Discussion}

The in vitro culture of oviductal cells has provided a suitable model for the study of the mechanisms involved in the interaction of gametes and embryos with the mammalian oviduct. Recent advances in in vitro modeling of the oviductal epithelium of different species, including bovine, porcine and human, have enabled the development of new culture techniques that better mimic the morphological and physiological characteristics of the oviduct (Gualtieri et al. 2012, Chen et al. 2013, Lawrenson et al. 2013, Simintiras et al. 2017). However, considering the increasing complexity of studies aimed at understanding the regulatory mechanisms that control embryo-maternal communication at a molecular level, it is necessary to establish novel strategies for in vitro culture that allow a more controlled interaction, in terms of area and contact time, between the embryo and the oviductal cells.

The main objective of the present study was to evaluate if the interaction of the embryo with the oviduct can induce changes in the gene expression of BMP signaling components. Considering the limitation of carrying out this study in vivo, an in vitro co-culture system was established to study the interaction between isthmus epithelial cells and in vitro-produced bovine embryos at developmental stages during which, under 


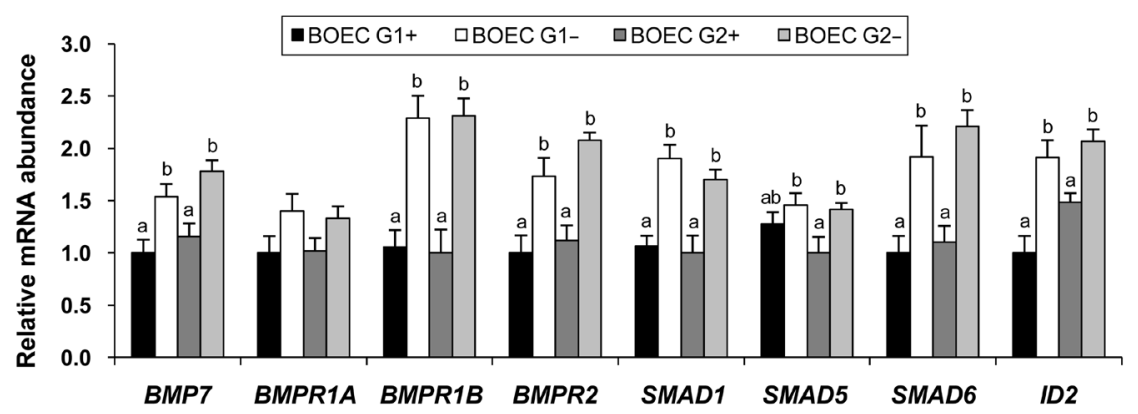

Figure 4 Relative mRNA abundance of BMP signaling-related genes in BOEC cultured in the presence or absence of early embryos, before or during embryonic genome activation. BOEC G1+: bovine oviductal epithelial cells cultured with embryos from 2-cell to 8-cell stage (33-54 hpi). BOEC G1-: bovine oviductal epithelial cells cultured in the absence of embryos from $33 \mathrm{hpi}$ to $54 \mathrm{hpi}$. BOEC G2+: bovine oviductal epithelial cells cultured with embryos from 8-cell to 16-cell stages (54-98 hpi). BOEC G2-: bovine oviductal epithelial cells cultured in the absence of embryos from $54 \mathrm{hpi}$ to $98 \mathrm{hpi}$. Bars represent the relative abundance of the transcripts analyzed and normalized to H2AFZ and ACTB as housekeeping genes. The experimental groups are represented by columns. Results are expressed as means \pm S.E.M. Different superscripts letters indicate significant differences $(P<0.05)$ between treatments. Data were obtained from five replicates of independent BOEC samples per experimental group.

physiological conditions, the embryo makes contact with the oviduct. To provide a local interaction, the area of contact between the embryo and the monolayer of oviductal cells was controlled and delimited with a polyester mesh. Moreover, a temporal interaction was established by analyzing two periods of embryonic development: before (from the 2-cell to 8-cell stage) and during (from the 8-cell to 16-cell stage) the main phase of embryonic genome activation (EGA). These two time windows were established taking into account that bovine embryonic genome is gradually activated, starting with minor activation, presumably initiated at the 2-cell stage and followed by a major activation at the 8- to 16-cell stage (Gad et al. 2012, Graf et al. 2014).

Embryos derived from the different experimental groups that were co-cultured with BOEC showed an early delay in developmental kinetics compared to embryos cultured without oviductal cells. However, this initial delay had no impact on the final production rate of blastocysts. A negative effect of the polyester mesh
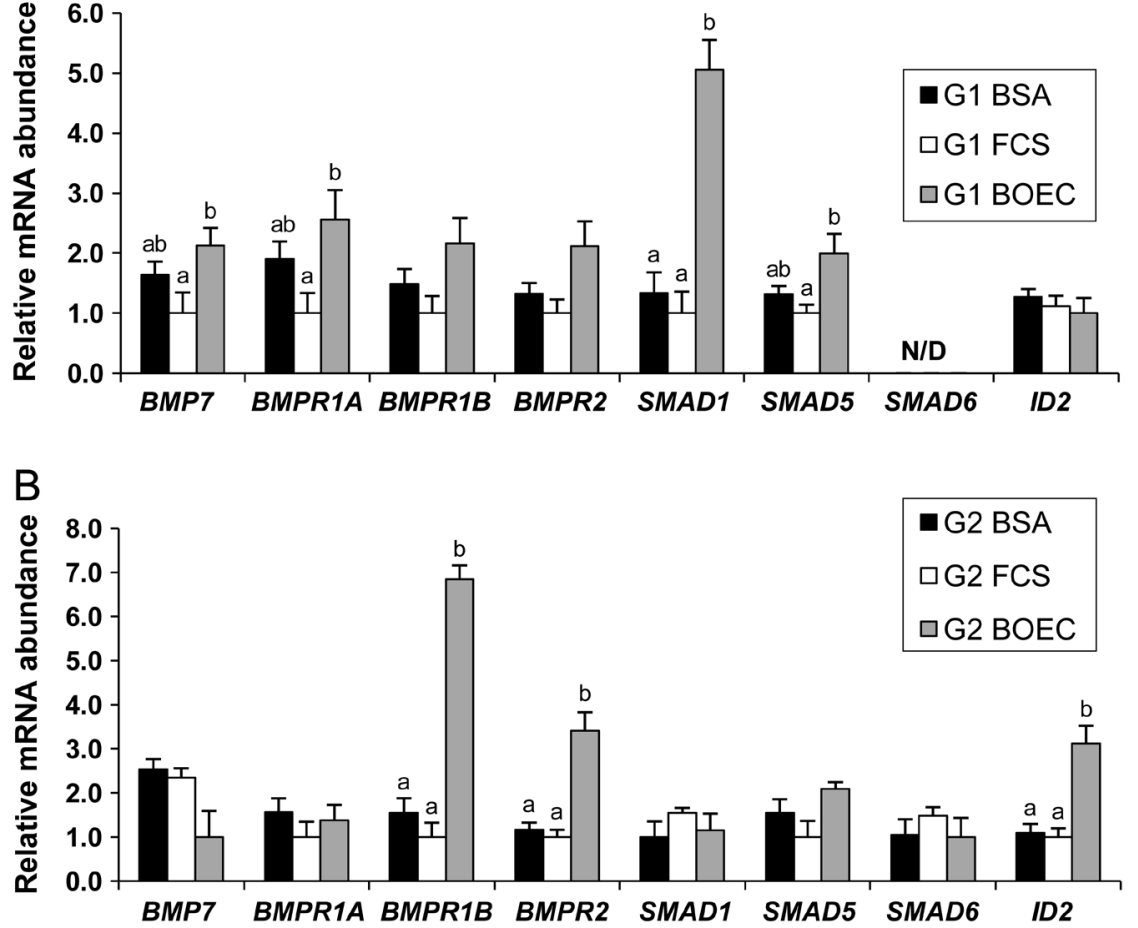

Figure 5 Relative mRNA abundance of BMP signaling-related genes in in vitro-produced bovine embryos cultured in the presence or absence of BOEC, before or during embryonic genome activation. (A) Bars represent the relative abundance of BMP signaling transcripts measured in 8-cell stage embryos obtained from experimental groups that were cultured from 2-cell stage to 8-cell stage in medium SOF + BSA (G1 BSA), SOF + FCS (G1 FCS) or co-cultured with a BOEC monolayer (G1 BOEC). (B) Bars represent the relative abundance of BMP signaling transcripts measured in 16-cell stage embryos obtained from experimental groups that were cultured from 8-cell stage to 16-cell stage in medium SOF + BSA (G2 BSA), SOF+FCS (G2 FCS) or co-cultured with a BOEC monolayer (G2 BOEC). The relative abundance of the transcripts was normalized to $H 2 A F Z$ and $A C T B$ as housekeeping genes. The control groups (G1/G2 BSA and G1/G2 FCS) are represented by black and white columns, while embryos cultured with oviductal cells are represented by grey columns. Results are expressed as mean \pm S.E.M. Different superscripts letters indicate significant differences $(P<0.05)$ between experimental groups. Data were obtained from three replicates of independent groups of 10 embryos per stage and experimental group. 

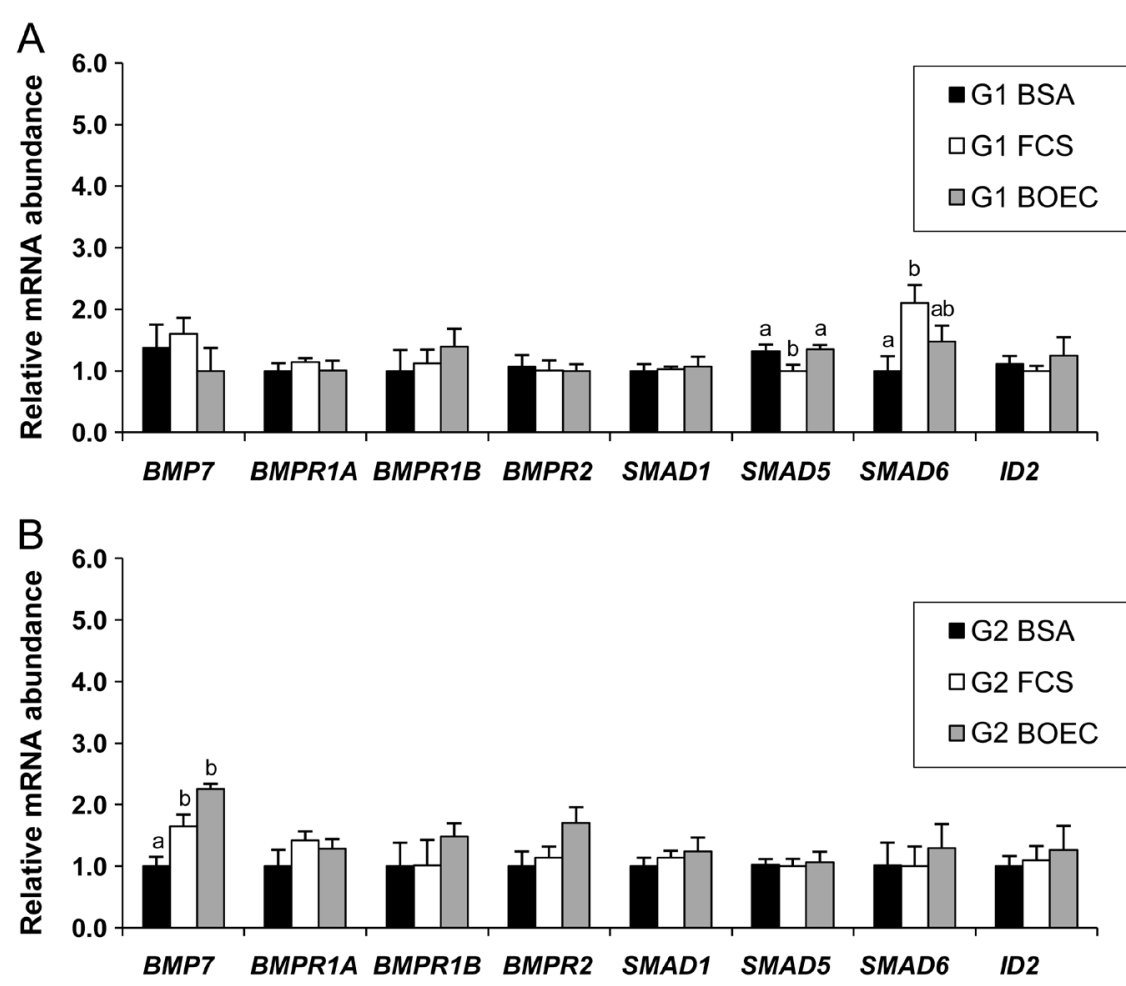

Figure 6 Relative mRNA abundance of BMP signaling-related genes in bovine blastocysts obtained from embryos co-cultured in vitro before or during embryonic genome activation in the presence or absence of BOEC. (A) Bars represent the relative abundance of BMP signaling transcripts measured in blastocysts derived from embryos cultured from the 2-cell stage to the 8-cell stage in the absence (G1 BSA and G1 FCS) or presence of a BOEC monolayer (G1 BOEC). (B) Bars represent the relative abundance of BMP signaling transcripts measured in blastocysts derived from embryos cultured from the 8 -cell stage to the 16-cell stage in the absence (G2 BSA and G2 FCS) or presence of a BOEC monolayer (G2 BOEC). The relative abundance of the transcripts was normalized to $H 2 A F Z$ and $A C T B$ as housekeeping genes. The control groups (G1/ G2 BSA and G1/G2 FCS) are represented by black and white columns, while groups cultured with oviductal cells are represented by grey columns. Results are expressed as mean \pm S.E.M. Different superscripts letters indicate significant differences $(P<0.05)$ between groups. Data were obtained from three replicates of independent groups of 10 blastocysts per experimental group. was ruled out as control embryos cultured without BOEC showed normal development in the presence of the mesh. In concordance with this fact, Matoba and coworkers (Matoba et al. 2010) showed that the same type of mesh has no effect on embryonic development in vitro.

Other studies reported that the in vitro co-culture of BOEC with bovine embryos during the first 4 days (Rief et al. 2002, Cordova et al. 2014) or the entire 8 days of embryo development (Schmaltz-Panneau et al. $2014,2015)$ can improve the early cleavage rate and/or the development to the blastocyst stage. Undoubtedly, the time of co-culture and the culture conditions are variables that have to be considered before evaluating and comparing these results. In particular, in the present study, the time of co-culture evaluated was shorter than that used in those studies. This allows to infer that an extended co-culture time between the embryo and the oviductal cells seems to be necessary to improve embryo development rate. In fact, other authors have shown that the embryotrophic effect of human oviductal cells cultured with mouse embryos is enhanced when the time of co-culture is longer and it lasts for at least four days (Xu et al. 2001).

On the other hand, gene expression analysis showed that the interaction with the embryos, before and during EGA, induced a significant decrease in the transcriptional levels of BMP signaling components in oviductal cells cultured in vitro. In particular, this reduction was observed in the mRNA levels of one ligand (BMP7), two receptors (BMPR1B and BMPR2), one signaling mediator (SMAD1) and two BMP target genes (SMAD6 and ID2). As can be seen, the effect is observed in all the genes encoding factors required for the signal transduction, suggesting a possible decrease in the activity of BMP pathway in the oviduct when the embryo is present.

It has been reported that BMP7 has a critical role in the oviduct, by acting as an inductor of apoptosis during tissue remodeling (Monroe et al. 2000). In fact, estrogen exerts a protective role by reducing the expression of this factor in the oviductal epithelium (Monroe et al. 2002, Kusumegi et al. 2004). Considering this, it would be interesting to explore if the downregulation of $B M P 7$ expression, induced by the presence of the embryo, could be associated with a protective effect in order to maintain the integrity of the oviduct as the embryo passes.

In reference to BMP receptors, previous studies demonstrated the expression of BMPR1B and BMPR2 in the bovine embryo, showing high abundance of their transcripts at the early embryonic stages (from 2-cell stage to 8-cell stage) (Garcia et al. 2015). This temporal gene expression pattern of the receptors suggests that the embryo could respond to BMP ligands during the first developmental stages during transit through the oviduct. Based on the present study, the mRNA expression of the same receptors was detected in the oviductal cells and the presence of the embryo downregulated their expression. In this sense, the embryo could be sending 
specific signals to reduce the expression levels of these receptors in the oviduct to avoid competence. If so, BMP ligands present in the oviductal microenvironment could act preferably on the embryo. However, further studies are required to confirm this possibility.

Downregulation of mRNA expression of SMAD1 and the target genes ID2 and SMAD6 is also indicative of a suppressed BMP pathway as a response of the oviduct to the embryo. This coincides with a previous study performed in vivo in which the transfer of 50 embryos to the bovine oviduct produced changes in the gene expression pattern of the oviductal cells; SMAD6 was among the genes downregulated by the embryo presence (Maillo et al. 2015). This gene is induced via SMAD1/5 pathway, and at protein level, it acts as an inhibitor self-regulated by the BMP signaling pathway (Ishida et al. 2000, Li 2015). A recent study in mice demonstrated that SMAD signaling is required for structural integrity of the female reproductive tract and uterine function during early pregnancy (Rodriguez et al. 2016). However, until now, little is known about its role in the oviduct, in particular during the early stages of embryo development.

Similarly to other studies (Cordova et al. 2014, Schmaltz-Panneau et al. 2014, Maillo et al. 2015) these results confirm that bovine embryos can have a direct effect on the transcriptome of the oviductal cells. However, it is important to note that this study, in contrast to others, demonstrates that a short period of interaction with the early embryo is sufficient to induce specific transcriptional changes in the oviductal cells. Furthermore, a similar transcriptional response was observed irrespective of the embryonic stage, suggesting that oviductal cells do not show a temporal sensitivity to the different stages of embryo development, at least in the conditions assayed and for the genes analyzed.

On the other hand, gene expression analysis of the embryos revealed significant changes in the expression profile of BMP genes depending on whether they interact with oviductal cells before or during EGA. Embryos that interacted with BOEC before the main phase of EGA (G1 BOEC) showed higher levels of transcripts associated with BMP signaling. Particularly, a significant increase in the relative abundance of SMAD1 mRNA was observed at the 8-cell stage, compared to control groups cultured without BOEC. SMAD1 is a key component of the BMP signaling pathway that allows the transduction of the signal from membrane receptors to the nucleus (Bragdon et al. 2011). Depending on cell response, SMAD1 or SMAD5 can be activated (Li 2015). Thus, the significant increase in the mRNA levels for SMAD1 in the embryos suggests that the interaction with oviductal cells may induce the activation of BMP signaling in the embryos through the SMAD1 pathway. In mouse embryos, Smad1 coordinates the growth of extra-embryonic structures necessary to support embryo development within the uterine environment. As a consequence, the failure of $S m a d 1$ signal induces defects in extra-embryonic tissues and knockout embryos die due to problems in placentation (Tremblay et al. 2001, Arnold et al. 2006, Li 2015). Transcriptional analysis of mouse and bovine embryos reveals high abundance of SMAD1 mRNA at early stages before the main phase of EGA and a significant reduction after EGA up to the blastocyst stage (Wang et al. 2004, Lee et al. 2014) suggesting that this factor is necessary during the early stages in which the embryo transits through the oviduct. In this sense, our results suggest that early embryo-oviduct interaction could have a critical role in maintaining high transcriptional levels of this factor before EGA, during the early stages in which the embryo interacts with the oviduct.

In the case of the embryos that interacted with BOEC during EGA (G2 BOEC), a significant increase in the relative abundance of $B M P R 1 B, B M P R 2$ and ID2 mRNA was detected at the 16-cell stage. This suggests that contact with the oviductal cells might induce the activation of the BMP signaling pathway in the embryo during the early stages of development. However, the precise mechanisms that control this upregulation are still unknown. It is well known that both BMP receptors, BMPR1B and BMPR2, play a critical role in preimplantation development and female fertility (Soyun et al. 2001, Nagashima et al. 2013, Graham et al. 2014, de Mochel et al. 2015). In addition, their transcript levels in the embryo are specifically elevated at early stages before EGA (Lee et al. 2014, Garcia et al. 2015). In the case of ID2, it is a target gene of BMP signaling and it acts as a transcription factor required for maintenance and differentiation of trophoblast cells (Janatpour et al. 2000, Roberts et al. 2004, Schiffmacher \& Keefer 2013). In agreement with our results, transcriptome analysis by microarray in in vivo-produced bovine embryos reported that ID2 increases its transcription during the activation of the bovine embryonic genome (Kues et al. 2008). The fact that the transcriptional levels of BMP receptors and the ID2 gene were higher during the early stages and stimulated by the interaction with the oviduct allows us to infer that BMP signaling pathway could be mediating an active cross talk between the embryo and the mother during the early stages of development.

Coincident with other studies (Wang et al. 2004, Zhang et al. 2007, Kues et al. 2008, Lee et al. 2014), our results show that during early embryogenesis, the transcript abundance of BMP signaling components is differentially regulated and that early maternalembryo interaction can have a critical impact on the transcriptional regulation of this signaling. Moreover, the low levels detected at the blastocyst stage and the fact that at this stage there were no differences in the mRNA expression levels of BMP signaling components supports the hypothesis that BMP signaling is more important during the early stages of development. In fact, the inhibition of this signaling at the beginning 
of embryo culture produces a significant reduction in the cleavage and developmental rates of mouse (de Mochel et al. 2015) and bovine embryos (La Rosa et al. 2011), suggesting that a correct balance of BMP signaling, during early stages, is needed for a proper preimplantation development. Thus, considering our results, the interaction with the oviduct could play a critical role to regulate this balance.

In conclusion, this study provides a new strategy for the study of the maternal-embryonic dialog and gives evidence about possible signaling pathways involved in the communication between the embryo and the bovine oviduct during the preimplantation period. The data presented demonstrate that local embryo-oviduct interaction in vitro induces changes in the transcriptional levels of BMP signaling, causing a bidirectional response that reduces the expression levels of this signaling in the oviductal cells while increasing them in the embryo at the early stages. These findings suggest that BMP signaling pathway could be involved in an early cross talk between the bovine embryo and the oviduct during first stages of development. Increased understanding of this intrinsic signaling for maternal-embryo communication is important for future improvements in ART and further understanding of the signaling pathways that potentially contribute to infertility in cattle and humans.

\section{Declaration of interest}

The authors declare that there is no conflict of interest that could be perceived as prejudicing the impartiality of the research reported.

\section{Funding}

This work was supported by grants from the Spanish Ministry of Economy and Competitiveness AGL2015-70140-R and AGL2015-66145-R.

\section{Acknowledgments}

The authors would like to thank Paula Beltrán and Carolina Nuñez for their technical assistance in the IVF assays, Laura Suarez Lorca and Leticia Fidalgo for their kind help in sample collection and experimental support and also to the slaughterhouse of Transformación Ganadera de Leganés (Madrid, Spain) for providing the biological material used in this study. Special thanks are extended to Professor Pat Lonergan from University College Dublin for his critical reading of the manuscript.

\section{References}

Almiñana C, Heath PR, Wilkinson S, Sanchez-Osorio J, Cuello C, Parrilla I, Gil MA, Vazquez JL, Vazquez JM, Roca J et al. 2012 Early developing pig embryos mediate their own environment in the maternal tract. PLOS ONE 7 e33625. (doi:10.1371/journal.pone.0033625)
Arnold SJ, Maretto S, Islam A, Bikoff EK \& Robertson EJ 2006 Dosedependent Smad1, Smad5 and Smad8 signaling in the early mouse embryo. Developmental Biology 296 104-118. (doi:10.1016/j. ydbio.2006.04.442)

Aviles M, Gutierrez-Adan A \& Coy P 2010 Oviductal secretions: will they be key factors for the future ARTs? Molecular Human Reproduction $\mathbf{1 6}$ 896-906. (doi:10.1093/molehr/gaq056)

Bermejo-Alvarez P, Rizos D, Rath D, Lonergan P \& Gutierrez-Adan A 2008 Epigenetic differences between male and female bovine blastocysts produced in vitro. Physiological Genomics 32 264-272. (doi:10.1152/ physiolgenomics.00234.2007)

Beyer TA, Narimatsu M, Weiss A, David L \& Wrana JL 2013 The TGFbeta superfamily in stem cell biology and early mammalian embryonic development. Biochimica et Biophysica Acta 1830 2268-2279. (doi:10.1016/j.bbagen.2012.08.025)

Bragdon B, Moseychuk O, Saldanha S, King D, Julian J \& Nohe A 2011 Bone morphogenetic proteins: a critical review. Cell Signaling 23 609-620. (doi:10.1016/j.cellsig.2010.10.003)

Buhi WC, Alvarez IM \& Kouba AJ 2000 Secreted proteins of the oviduct. Cells Tissues Organs 166 165-179. (doi:10.1159/000016731)

Bustin SA, Benes V, Garson JA, Hellemans J, Huggett J, Kubista M, Mueller R, Nolan T, Pfaffl MW, Shipley GL et al. 2009 The MIQE guidelines: minimum information for publication of quantitative realtime PCR experiments. Clinical Chemistry 55 611-622. (doi:10.1373/ clinchem.2008.112797)

Cordova A, Perreau C, Uzbekova S, Ponsart C, Locatelli Y \& Mermillod P 2014 Development rate and gene expression of IVP bovine embryos cocultured with bovine oviduct epithelial cells at early or late stage of preimplantation development. Theriogenology $\mathbf{8 1}$ 1163-1173. (doi:10.1016/j.theriogenology.2014.01.012)

Chen S, Einspanier R \& Schoen J 2013 In vitro mimicking of estrous cycle stages in porcine oviduct epithelium cells: estradiol and progesterone regulate differentiation, gene expression, and cellular function. Biology of Reproduction 89 54. (doi:10.1095/biolreprod.113.108829)

de Mochel NSR, Luong M, Chiang M, Javier AL, Luu E, Toshihiko F, MacGregor GR, Cinquin O \& Cho KW 2015 BMP signaling is required for cell cleavage in preimplantation-mouse embryos. Developmental Biology 397 45-55. (doi:10.1016/j.ydbio.2014.10.001)

Fazeli A 2008 Maternal communication with gametes and embryos. Theriogenology 70 1182-1187. (doi:10.1016/j. theriogenology.2008.06.010)

Gad A, Hoelker M, Besenfelder U, Havlicek V, Cinar U, Rings F, Held E, Dufort I, Sirard MA, Schellander K et al. 2012 Molecular mechanisms and pathways involved in bovine embryonic genome activation and their regulation by alternative in vivo and in vitro culture conditions. Biology of Reproduction 87 100. (doi:10.1093/biolreprod/87.s1.100)

Garcia EV, Valdecantos PA, Barrera D, Roldan-Olarte M \& Miceli DC 2014 Bonemorphogenetic proteins in thebovineoviduct: differential expression of BMP-5 in the isthmus during the estrous cycle. Theriogenology $\mathbf{8 1}$ 1032-1041. (doi:10.1016/j.theriogenology.2014.01.025)

Garcia EV, Miceli DC, Rizo G, Valdecantos PA \& Barrera AD 2015 Effect of early addition of bone morphogenetic protein 5 (BMP5) to embryo culture medium on in vitro development and expression of developmentally important genes in bovine preimplantation embryos. Theriogenology 84 589-599. (doi:10.1016/j.theriogenology.2015.04.018)

Graf A, Krebs S, Zakhartchenko V, Schwalb B, Blum H \& Wolf E 2014 Fine mapping of genome activation in bovine embryos by RNA sequencing. PNAS 111 4139-4144. (doi:10.1073/pnas.1321569111)

Graham SJ, Wicher KB, Jedrusik A, Guo G, Herath W, Robson P \& Zernicka-Goetz M 2014 BMP signalling regulates the pre-implantation development of extra-embryonic cell lineages in the mouse embryo. Nature Communications 5 5667. (doi:10.1038/ncomms6667)

Gualtieri R, Mollo V, Braun S, Barbato V, Fiorentino I \& Talevi R 2012 Long-term viability and differentiation of bovine oviductal monolayers: bidimensional versus three-dimensional culture. Theriogenology $\mathbf{7 8}$ 1456-1464. (doi:10.1016/j.theriogenology.2012.06.010)

Ireland JJ, Murphee R \& Coulson P 1980 Accuracy of predicting stages of bovine estrous cycle by gross appearance of the corpus luteum. Journal of Dairy Science 63 155-160. (doi:10.3168/jds.S00220302(80)82901-8)

Ishida W, Hamamoto T, Kusanagi K, Yagi K, Kawabata M, Takehara K, Sampath TK, Kato M \& Miyazono K 2000 Smad6 is a Smad1/5-induced 
smad inhibitor. Characterization of bone morphogenetic proteinresponsive element in the mouse Smad6 promoter. Journal of Biological Chemistry 275 6075-6079. (doi:10.1074/jbc.275.9.6075)

Janatpour MJ, McMaster MT, Genbacev O, Zhou Y, Dong J, Cross JC, Israel MA \& Fisher SJ 2000 Id-2 regulates critical aspects of human cytotrophoblast differentiation, invasion and migration. Development 127 549-558.

Jones RL, Stoikos C, Findlay JK \& Salamonsen LA 2006 TGF-beta superfamily expression and actions in the endometrium and placenta. Reproduction 132 217-232. (doi:10.1530/rep.1.01076)

Kishigami S \& Mishina Y 2005 BMP signaling and early embryonic patterning. Cytokine Growth Factor Reviews 16 265-278. (doi:10.1016/j. cytogfr.2005.04.002)

Knight PG \& Glister C 2006 TGF-beta superfamily members and ovarian follicle development. Reproduction 132 191-206. (doi:10.1530/ rep.1.01074)

Kues WA, Sudheer S, Herrmann D, Carnwath JW, Havlicek V, Besenfelder U, Lehrach H, Adjaye J \& Niemann H 2008 Genome-wide expression profiling reveals distinct clusters of transcriptional regulation during bovine preimplantation development in vivo. PNAS 105 19768-19773. (doi:10.1073/pnas.0805616105)

Kusumegi T, Tanaka J, Kawano M, Yonemoto J, Tohyama C \& Sone H 2004 BMP7/ActRIIB regulates estrogen-dependent apoptosis: new biomarkers for environmental estrogens. Journal of Biochemical and Molecular Toxicology 18 1-11. (doi:10.1002/jbt.20004)

La Rosa I, Camargo L, Pereira MM, Fernandez-Martin R, Paz DA \& Salamone DF 2011 Effects of bone morphogenic protein 4 (BMP4) and its inhibitor, Noggin, on in vitro maturation and culture of bovine preimplantation embryos. Reproductive Biology and Endocrinology 9 18. (doi:10.1186/1477-7827-9-18)

Lawrenson K, Notaridou M, Lee N, Benjamin E, Jacobs IJ, Jones C \& Gayther SA 2013 In vitro three-dimensional modeling of fallopian tube secretory epithelial cells. BMC Cell Biology 14 43. (doi:10.1186/14712121-14-43)

Lee KF \& Yeung WS 2006 Gamete/embryo - oviduct interactions: implications on in vitro culture. Human Fertility 9 137-143. (doi:10.1080/14647270600636467)

Lee KF, Yao YQ, Kwok KL, Xu JS \& Yeung WS 2002 Early developing embryos affect the gene expression patterns in the mouse oviduct. Biochemical and Biophysical Research Communications 292 564-570. (doi:10.1006/bbrc.2002.6676)

Lee KB, Folger JK, Rajput SK \& Smith GW 2014 Temporal regulation of mRNAs for select bone morphogenetic proteins (BMP), BMP receptors and their associated SMAD proteins during bovine early embryonic development: effects of exogenous BMP2 on embryo developmental progression. Reproductive Biology and Endocrinology 1267. (doi:10.1186/1477-7827-12-67)

Li Q 2015 Inhibitory SMADs: potential regulators of ovarian function. Biology of Reproduction 92 50. (doi:10.1095/biolreprod.115.128603)

Livak KJ \& Schmittgen TD 2001 Analysis of relative gene expression data using real-time quantitative PCR and the 2(-Delta Delta C(T)) method. Methods 25 402-408. (doi:10.1006/meth.2001.1262)

Lonergan P, Khatir H, Piumi F, Rieger D, Humblot P \& Boland MP 1999 Effect of time interval from insemination to first cleavage on the developmental characteristics, sex ratio and pregnancy rate after transfer of bovine embryos. Journal of Reproduction and Infertility 117 159-167. (doi:10.1530/jrf.0.1170159)

Lopera-Vásquez R, Hamdi M, Maillo V, Lloreda V, Coy P, GutierrezAdan A, Bermejo-Alvarez P \& Rizos D 2015 Effect of bovine oviductal fluid on development and quality of bovine embryos produced in vitro. Reproduction Fertility and Development $29621-629$ (doi:10.1071/ rd15238)

Lopera-Vásquez R, Hamdi $M$, Fernandez-Fuertes B, Maillo V, BeltránBreña $P$, Calle A, Redruello A, López-Martín S, Gutierrez-Adán A, Yañez-Mó M et al. 2016 Extracellular vesicles from BOEC in in vitro embryo development and quality. PLOS ONE 11 e0148083. (doi: 10.1371/journal.pone.0148083)

Maillo V, Gaora PO, Forde N, Besenfelder U, Havlicek V, Burns GW, Spencer TE, Gutierrez-Adan A, Lonergan P \& Rizos D 2015 Oviductembryo interactions in cattle: two-way traffic or a one-way street? Biology of Reproduction 92 144. (doi:10.1095/biolreprod.115.127969)

Maillo V, Lopera-Vasquez R, Hamdi M, Gutierrez-Adan A, Lonergan P \& Rizos D 2016 Maternal-embryo interaction in the bovine oviduct: evidence from in vivo and in vitro studies. Theriogenology 86 443-450. (doi:10.1016/j.theriogenology.2016.04.060)

Matoba S, Fair T \& Lonergan P 2010 Maturation, fertilisation and culture of bovine oocytes and embryos in an individually identifiable manner: a tool for studying oocyte developmental competence. Reproduction Fertility and Development 22 839-851. (doi:10.1071/RD09277)

Memili E \& First NL 2000 Zygotic and embryonic gene expression in cow: a review of timing and mechanisms of early gene expression as compared with other species. Zygote 8 87-96. (doi:10.1017/S0967199400000861)

Monroe DG, Jin DF \& Sanders MM 2000 Estrogen opposes the apoptotic effects of bone morphogenetic protein 7 on tissue remodeling. Molecular and Cellular Biology 20 4626-4634. (doi:10.1128/MCB.20.13.46264634.2000)

Monroe DG, Berger RR \& Sanders MM 2002 Tissue-protective effects of estrogen involve regulation of caspase gene expression. Journal of Molecular Endocrinology 16 1322-1331. (doi:10.1210/ mend.16.6.0855)

Nagashima T, Li Q, Clementi C, Lydon JP, DeMayo FJ \& Matzuk MM 2013 BMPR2 is required for postimplantation uterine function and pregnancy maintenance. Journal of Clinical Investigation 123 2539-2550. (doi:10.1172/JCI65710)

Rief S, Sinowatz F, Stojkovic M, Einspanier R, Wolf E \& Prelle K 2002 Effects of a novel co-culture system on development, metabolism and gene expression of bovine embryos produced in vitro. Reproduction 124 543-556. (doi:10.1530/rep.0.1240543)

Rizos D, Maillo V \& Lonergan P 2016 Role of the oviduct and oviductderived products in ruminant embryo development. Animal Reproduction 13 160-167. (doi:10.21451/1984-3143-AR863)

Roberts RM, Ezashi T \& Das P 2004 Trophoblast gene expression: transcription factors in the specification of early trophoblast. Reproductive Biology and Endocrinology 2 47. (doi:10.1186/1477-7827-2-47)

Rodriguez A, Tripurani SK, Burton JC, Clementi C, Larina I \& Pangas SA 2016 SMAD signaling is required for structural integrity of the female reproductive tract and uterine function during early pregnancy in mice 1. Biology of Reproduction 95 44. (doi:10.1095/biolreprod.116.139477)

Roelen BA, Goumans MJ, van Rooijen MA \& Mummery CL 1997 Differential expression of BMP receptors in early mouse development. International Journal of Developmental Biology 41 541-549.

Schiffmacher AT \& Keefer CL 2013 CDX2 regulates multiple trophoblast genes in bovine trophectoderm CT-1 cells. Molecular Reproduction and Development 80 826-839. (doi:10.1002/mrd.22212)

Schmaltz-Panneau B, Cordova A, Dhorne-Pollet S, Hennequet-Antier C, Uzbekova S, Martinot E, Doret S, Martin P, Mermillod P \& Locatelli Y 2014 Early bovine embryos regulate oviduct epithelial cell gene expression during in vitro co-culture. Animal Reproduction Science 149 103-116. (doi:10.1016/j.anireprosci.2014.06.022)

Schmaltz-Panneau B, Locatelli Y, Uzbekova S, Perreau C \& Mermillod P 2015 Bovine oviduct epithelial cells dedifferentiate partly in culture, while maintaining their ability to improve early embryo development rate and quality. Reproduction in Domestic Animals 50 719-729. (doi:10.1111/rda.12556)

Schmittgen TD \& Livak KJ 2008 Analyzing real-time PCR data by the comparative C(T) method. Nature Protocols 3 1101-1108. (doi:10.1038/ nprot.2008.73)

Shimasaki S, Moore RK, Otsuka F \& Erickson GF 2004 The bone morphogenetic protein system in mammalian reproduction. Endocrine Reviews 25 72-101. (doi:10.1210/er.2003-0007)

Simintiras CA, Fröhlich T, Sathyapalan T, Arnold G, Ulbrich SE, Leese HJ \& Sturmey RG 2017 Modelling aspects of oviduct fluid formation in vitro. Reproduction 153 23-33. (doi:10.1530/REP-15-0508)

Smits K, De Coninck DI, Van Nieuwerburgh F, Govaere J, Van Poucke M, Peelman L, Deforce D \& Van Soom A 2016 The equine embryo influences immune-related gene expression in the oviduct. Biology of Reproduction 94 36. (doi:10.1095/biolreprod.115.136432)

Soyun EY, LaPolt PS, Yoon BS, Chen JY-C, Lu JK \& Lyons KM 2001 The type I BMP receptor BmprIB is essential for female reproductive function. PNAS 98 7994-7999. (doi:10.1073/pnas.141002798)

Tremblay KD, Dunn NR \& Robertson EJ 2001 Mouse embryos lacking Smad1 signals display defects in extra-embryonic tissues and germ cell formation. Development 128 3609-3621.

Wang QT, Piotrowska K, Ciemerych MA, Milenkovic L, Scott MP, Davis RW \& Zernicka-Goetz M 2004 A genome-wide study of gene activity reveals developmental signaling pathways in the preimplantation 
mouse embryo. Developmental Cell 6 133-144. (doi:10.1016/S15345807(03)00404-0)

Wolf E, Arnold GJ, Bauersachs S, Beier HM, Blum H, Einspanier R, Frohlich T, Herrler A, Hiendleder S, Kolle S et al. 2003 Embryo-maternal communication in bovine - strategies for deciphering a complex crosstalk. Reproduction in Domestic Animals 38 276-289. (doi:10.1046/ j.1439-0531.2003.00435.x)

Xu JS, Cheung TM, Chan ST, Ho PC \& Yeung WS 2001 Temporal effect of human oviductal cell and its derived embryotrophic factors on mouse embryo development. Biology of Reproduction 65 1481-1488. (doi:10.1095/biolreprod65.5.1481)
Zhang Y, Yang Z \& Wu J 2007 Signaling pathways and preimplantation development of mammalian embryos. FEBS Journal 274 4349-4359. (doi:10.1111/j.1742-4658.2007.05980.x)

Received 6 December 2016

First decision 10 January 2017

Revised manuscript received 9 February 2017

Accepted 28 February 2017 